Saeculum Christianum

vol. XXIII (2016)

pp. 194-213

ADAM BUŁAWA

WNHiS UKSW, Warszawa

\title{
"THE HUNGARIAN TRACK". FROM THE SPRING OF NATIONS (1848-1849) IN THE TERRITORY OF THE CROWN OF SAINT STEPHEN TO THE POLISH UPRISINGS (1863-1864), VOL. I
}

From among the military campaigns carried out between 1830 and 1863 the Hungarian Revolution of 1848 involved the largest percentage share (approx. 11-23\%) of the selected group of the future leaders of the January Uprising $(237)^{1}$. Thus it is prudent to closely examine their involvement in the anti-Habsburg uprising.

The historical borders of the Kingdom of Hungary (the Crown of St. Stephen) encompassed the Northern Great Plain, Slovakia, Bačka and Banat, Croatia, Slavonia and Dalmatia as well as Transcarpatian Ruthenia. The military actions (September 1848 - September/October 1849) engulfed the first four regions. On the 20th of April 1848 the Hungarian authorities established the National Guard and, on the initiative of Prime Minister Lajos Batthyány, on the 15th of May the Hungarian military independent from the Habsburg army was called to arms. These units consisted of volunteers enlisted for a period of 4 years, equipped with national uniforms and remunerated similarly to the "imperial" soldiers, and served under the name of "honveds" which is a language calque of the German word Landwehr (a defender of homeland) ${ }^{2}$. Although the army of ban (a Hungary-specific title) Josip Jelacic entered Hungary on the 4th of September and claimed its first victory on the 29th of September 1848 during the revolution in Pakozd, the war with Austria started on the 3rd of October 1848 when Ferdinand I unlawfully dissolved the Hungarian National Assembly.

For the Poles the fact that Hungarians entered into conflict with one of the partitioners suggested, independently of the traditional bonds of friendship between Poland and Hungary, to support Hungary in accordance with the Polish political interests, ideally through the use of a Legion, a formation developed over the course of the last half of the century ${ }^{3}$.

\footnotetext{
Being the commander in at least one battle is the criterium for distinguishing a group: Leon Czachowski, Edward Dunajewski, Wiktor Dobrosielski, Narcyz Figietty, Franciszek Horodyński, Józef Jagmin, Antoni Jeziorański, Zygmunt Jordan, Karol Kalita, Walery Kozłowski, Walenty Lewandowski, Aleksander Matuszewicz, Zygmunt Miłkowski, Władysław Miśkiewicz, Ignacy Mystkowski, Julian Nadmiller, Władysław Józef Rucki, Stanisław Szumlański, Edmund Ślaski, Tomasz Wierzbicki, Leszek Wiśniowski, Józef Wysocki.

2 I. Kovacs, Polacy w węgierskiej Wiośnie Ludów 1848-1849. „, Byliśmy z wami do końca”, Warszawa 1999, p. 66.

3 Z. Vesztroczy, Polski legion na Węgrzech w 1848-49 r., in: Pod wspólnym sztandarem. Polacy w węgierskiej Wiośnie Ludów, editor: A. Nagy, A. Laszlo, Polskie Stowarzyszenie Kulturalne im. J. Bema na Węgrzech, Budapest 1999, pp. 88-91.
} 
Józef Wysocki, promoted to the rank of major and appointed as the commander of the "Polish-Hungarian unit" referred to as Wysocki's battalion (17/18th of November 1848) went down in the history as the main organiser of the Polish Legion accompanying the Hungarian army ${ }^{4}$. As early as on the 20th of October 1848 the National Committee for the Defence of Homeland, the insurrectionary Hungarian government, entered into an agreement on foundation of a military unit with the committee for Magyar support in Lviv: volunteers received a national banner and uniforms (white coats with red rim, grey and blue trousers and red four-cornered caps lined with fleece) $)^{5}$ and permission to speak their native language among the ranks of the unit. It was expected that 1200 soldiers would enlist (a battalion of infantry, a squadron of uhlan lancers and 1-2 artillery batteries) ${ }^{6}$.

The 300-men strong battalion (companies of Ignacy Czernik and Konstanty Matczyński) 7 joined the siege of Arad (4th of December 1848). Although the stronghold garrisoned with 1500 men commanded by Fieldmarshal Johan Berger von der Pleisse was of a secondary importance to the Habsburg Empire, conquering it was a prerequisite for laying a siege to the stronghold in Temesvar, the capital of Bačka, which would in turn shift the balance of power in that region, in Bačka and in Transylvania. Two battalions of Hungarian highlanders - Székelys, two battalions of honveds and 4 companies of the National Guard from Debreczyn led by lieutenant colonel Janos Mariassy participated in the siege ${ }^{8}$. The volunteers from Debreczyn, 4 companies from the 29th battalion of honveds and 5 companies from the 30th battalion were delegated to participate in the December assault. Owing to the violation of silence and insufficient preparations and due to the lack of military hardware, among other factors, the Polish baptism of fire resulted in a defeat ${ }^{9}$. The new commander of the siege, colonel-engineer Miklos Gaal and government commissar Daniel Boczko appreciated the devotion of the Poles and their commander. The mission of the Poles was to secure and defend a river crossing during the skirmish with the group of general Christian Leiningen in Nowy Arad (3 infantry battalions, a regiment of cavalry, 12 cannons), which ended in Hungarians

4 E. Kozłowski, Generał Józef Bem, Warszawa 1958, p. 293; idem, in: Zarys dziejów wojskowości do 1864 r., vol.1, part 2, editor A. Grabski, Warszawa 1966, pp. 473-474; J. Wimmer, Historia piechoty polskiej, Warszawa 1978, pp. 558-562; A. Szmyt, Generał Józef Wysocki w służbie wolności Polaków i Węgrów, Olsztyn 2001, p. 136; I. Kovacs, Nieznani polscy bohaterowie powstania węgierskiego 1848-1849, Warszawa 2010, p. 42.

5 T. Iskrzycki, Mundury formacji polskich na Wegrzech w latach 1848-1849, „Studia do Dziejów Dawnego Uzbrojenia i Ubioru Wojskowego", Kraków 1963, part 1, pp. 71; Z. Miłkowski, Od kolebki przez życie, Kraków 1936, vol. 1, p. 326; E. Kozłowski, Legion Polski na Wegrzech 1848-1849, Warszawa 1983, p. 98.

$6 \quad$ L. Russjan, Polacy i sprawa polska na Wegrzech w roku 1848-1849, Warszawa 1936, pp. 97-98; E. Kozłowski, Generał Józef Bem, pp. 286-287, idem, Legion Polski, p. 32; J. Bułharyn, Rys wojny węgierskiej w roku 1848 i 1849, Paryż 1852, pp. 47-48; J. Wysocki, Pamiętnik generała ... z czasów kampanii węgierskiej, Warszawa 1899, p. 6; J. Falkowski, Wspomnienia z roku 1848 i 1849, Warszawa 1908, part 1, p. 69; Z. Miłkowski, Od kolebki, vol. 1, p. 276; J. Grabowiecki, Moje wspomnienia z emigracji od roku 1831 do 1854, spisane w Marsylii, Warszawa 1970 , p. 145.

J. Wysocki, Pamiętnik, p. 12; I. Grabowiecki, Moje wspomnienia, p. 152.

8 E. Kozłowski, Legion Polski, p. 99-100; A. Szmyt, Generał Józef Wysocki, p. 139; I. Kovacs, Polacy w węgierskiej Wiośnie Ludów, pp. 134-136; idem, Nieznani polscy bohaterowie, p. 43.

9 W. Rucki, Z pamiętników żotnierza, „Dziennik Literacki”, 1862, no. 49, p. 398; Z. Miłkowski, Od kolebki, vol. 1., p. 280; A. Grochowalski, 1848 i 1849, Kampania na Węgrzech przez ..., sztabu korpusu 3-go węgierskiego, B. Czartoryskich, Kraków rkps 5326, pp. 312-313. 
having been driven behind the river line and the stronghold garrison having replenished its supplies (14th of December 1848) ${ }^{10}$.

At that time the Hungarian command agreed to form Władysław Poniński’s cavalry regiment ${ }^{11}$ equipped with the Austrian-style uniforms, red square-topped hats called "konfederatki [confederates]" and Hungarian pennons attached to lances later switched to navy blue uniforms with red shirtcuffs and caps ${ }^{12}$. It was this unit where Julian Nadmiller, the member of the Cracovian National Guard, and others ended up ${ }^{13}$. The presence of legionnaires during the siege did not allow them to gain any greater combat experience because apart from the two clashes mentioned previously they primarily handled garrison and patrol duties, engaged in small skirmishes and were characterised by poor discipline ${ }^{14}$.

Towards the end of December 1848 Lajos Kossuth appointed lieutenant colonel Jerzy Bułharyn as the commander-in-chief of all Polish legions in Hungary (with the exception of the legion of General Józef Bem, that was being formed in Transylvania at that time), which formally sanctioned the state of diarchy (Wysocki was his competitor for that position). Bułharyn took over the leadership of a small unit constituting the core of the 5th Legion Company in the so called Northern Corps under the overall command of the Minister of War, General Lazar Meszaros. The reorganised corps in Slovakia (Upper Hungary) consisted of ten thousand soldiers (more than 8000 infantrymen, 1600 cavalrymen and 34 cannons with crews).

Subordinates of Bułharyn fought and lost against the Galician corps under the command of Major General Count Franz Schlick von Bassano und Weisskirchen (3 brigades - namely 6.7-8 thousand soldiers) in the battles of Koszyce (4th of December) and Szinnye (22nd of December 1848) and in the attempt at retaking Koszyce (4th of January 1849) ${ }^{15}$. Antoni Jeziorański was already present in Władysław Tchórznicki's cavalry squadron, dismounted due to the lack of horses, of the 2nd hussar regiment attached to colonel Sandor Puszky's division (10-12 thousand men, 15 cannons $)^{16}$. His debut in combat was related with the previously mentioned defence of Góra Koszycka where the counter-assault of horseless Polish uhlan lancers and the 42nd battalion of honveds saved the divisional artillery (36 cannons with the crew of 660) fighting alongside 2-3 honvedian battalions and several units of National Guard infantry, approx. 1200 hussars and approx. 190 mounted guardsmen ${ }^{17}$. These dismounted uhlan lancers

10 E. Kozłowski, Legion Polski, p. 100; J. Bułharyn, Rys wojny, p. 61; W. Poniński, Wspomnienia z lat ubiegłych: listy do moich synów, Kraków 1902, p. 31.

11 E. Kozłowski, Legion Polski, pp. 99, pp. 100-102; P. Wodziński, Wspomnienia żotnierza-tułacza (1848-1863), Lwów 1912, p. 24; K. Kalita, Ze wspomnień krwawych walki, Lwów 1913; Z. Miłkowski, Od kolebki, vol. 1.

12 According to the Hungarian sources they were equipped with navy blue uniforms with trousers with white stripes and shirtcuffs and lappets of coats lined with red, blue caps with white tufts and lances with white and blue pennons attached.

13 E. Kozłowski, Julian Natmiller (1823-1903), PSB, vol. 23, Kraków 1977, pp. 618-619.

14 J. Bułharyn, Rys wojny, p. 58; W. Rucki, Z pamiętników żolnierza, p. 401; W. Poniński, Wspomnienia, s. 30; Z. Miłkowski, Od kolebki, vol. 1, pp. 286-287; S. Schnur-Pepłowski, Polacy $i$ Węrzy. Opowieść dziejowa z lat 1848 i 1849, Lwów 1896, pp. 120-121; A. Grochowalski, 1848 i 1849, Kampania na Wegrzech, pp. 310-311.

15 E. Kozłowski, Legion Polski, p. 86.

16 E. Kozłowski, Antoni Jeziorański (1821-1882), PSB, vol. 11, Kraków 1964-1965, pp. 215-216.

17 Ibidem, p. 87. 
ambushed the Austrian pursuit cavalry under the command of major Concorregio from the regiment of light horsemen and staff captain Sudsier (11th of December 1848) ${ }^{18}$.

Subordinates of Butharyn moved from the Northern Corps, routed in the beginning of 1849, to the Upper Cisa Corps under the command of colonel Georgy Klapka, formed on the foundation of the former Northern Corps and consisting of two divisions, each comprised of two brigades, and a separate brigade: Bułharyn was in command of brigades of major Istvan Zako and lieutenant colonel Władysław Tchórzecki (the 2nd battalion under the command of Tadeusz Idzikowski - 3 companies, a unit of cavalry from the 2nd uhlan lancers regiment, a battery of 3 cannons under the command of captain Grabowiecki - 120 infantrymen and 100 cavalrymen, including 350-380 Poles, according to other sources). The entirety of the corps consisted of 6110 infantrymen, 715 cavalrymen and 34 cannons ${ }^{19}$. Polish uhlan lancers were at that time dressed in navy blue jackets with white stripes, caps styled after the caps worn by soldiers in the Kingdom of Poland, and pennons with Hungarian and, later, Polish, national colours and colours of the regiment ${ }^{20}$.

Soon after Tchórznicki's cavalry became engaged in the unfavourable skirmish in Szanto (19th of January) where, despite the support from the company under the command of Hipolit Żółtkowski, it abandoned the defence line and, later, the clash in Tarczal near the foot of the Tokay mountain (21st of January). Two brigades of Schlick reinforced by the division of General Franz Schluzg fought for Teresienberg against the Cisa Corps, where the 2.5 thousandmen strong division of Bułharyn dealt the decisive blow leading to victory. Tchórznicki and his cavalrymen were among the units distinguished by Klapka who emphasised merits and service of the Poles during the battle and second lieutenant Jeziorański was one of numerous soldiers who received promotions. In February Tchórznicki began to form a unit of lancers in Nyiregyhaza and due to the lack of vacant officer positions, Jeziorański moved to the company of Antoni Wieruski, the 2nd battalion under the command of Idzikowski operating on the front in central Hungary ${ }^{21}$. Tomasz Wierzbicki was an officer of the hussars squadron from the 1st Galician regiment of Coburg which entered the corps of colonel Klapka, as a honved unit, who aimed at being transferred to the command of General Dembiński, and was in May 1849 assigned to the Petroveradin stronghold (Petervarad, Novi Sad) in southern Bačka that was under the siege of Jelecic's army ${ }^{22}$.

Towards the end of January 1849 Kossuth appointed General Henryk Dembiński as the commander-in-chief of the Hungarian forces (24602 infantrymen and cavalrymen, 75 cannons

18 E. Kozłowski, Legion Polski, p. 95; I. Kovacs, Polacy w węgierskiej Wiośnie Ludów, pp.162-169; A. Jeziorański, Pamiętniki jenerała... od roku 1848 do 1863, Lwów 1880, p. 25.

19 E. Kozłowski, Legion Polski, pp. 92-96, p. 112, pp. 153-154. According to other sources: 7925 infantrymen and 695 cavalrymen.

20 I. Grabowiecki, Moje wspomnienia, p. 151; A. Langie, Pamiętniki niedoli.... z lat 1849-1856, Kraków 1896, p. 20.

21 J. Helfert, Geschichte Osterreichs vom Ausgange des Wiener October-Ausfstandes 1848. Der ungarische Winterfeldzug Und die octroirte Verfassung, vol. 4, part 2, Prag-Leipzig 1886, p. 165, p. 489; R. Kissling, Die Revoluton im Kaisertum, vol. 2, Vienna 1948, p. 37; E. Kozłowski, Legion Polski, p. 157, p. 159; pp. 160-165; A. Jeziorański, Pamiętniki jenerała, vol. 1, pp. 44-56; J. Szyc, Legiony polskie na Węrzech. Wspomnienia officera tychże Legionów, Poznań 1850, p. 24; G. Klapka, Der Nationalkrieg in Ungarn und Sienburgen in den Jahren 1848 und 1849, vol. 1, Leipzig 1851, pp. 195-196; J. Bułharyn, Rys wojny, pp. 97-102; J. Wysocki, Pamiętnik, pp. 23-25; J. Grabowiecki, Moje wspomnienia, pp. 163-164.

22 I. Kovacs, Polacy w węgierskiej Wiośnie Ludów, p. 527; J. Łątka, Słownik Polaków w Imperium Osmańskim i Republice Tureckiej, Warszawa 2005, p. 159. 
which later expanded to 37 thousand men and 120 cannons in February) ${ }^{23}$. Zygmunt Jordan became his aide-de-camp ${ }^{24}$. The division of Bułharyn participated in Klapka's corps involved in the pursuit of Schlick. The battalion of Major Idzikowski with the support of 2 Hungarian companies and 4 cannons and with the assistance of a squadron of hussars distinguished itself in combat with the rearguard of Austrians by, among its other deeds, taking the bridge on the Hernada river near Hidasnemeti, set ablaze by the Austrians (8th of February) ${ }^{25}$. Apart from Jordan, Jeziorański also participated in those operations as well as in the twoday long battle in Kapolna (26-27th of February), which resulted in the defeat of the 30 thousand-men strong Hungarian army. On the first day the 120-men strong 2nd battalion of the Legion accompanied by 4 Hungarian companies, 4 cannons and a squadron of hussars, was engaged in the defence of the Szirok gorge and the fighting retreat through the bridges on the Tarna river, which it left intact, against 3 battalions from the brigade of General Kriegern accompanied by artillery; on the second day it was providing defence for the corps crossing a bridge on the Lasko stream near Kerecsend ${ }^{26}$.

The military career of Józef Wysocki began rapidly gaining momentum: since January he had been acting as a colonel, in February he was appointed as the commander of one of brigades (consisting of a Polish battalion formed from two companies, a single-squadron regiment of cavalry and 3rd and 9th battalions of honveds) of the ban division of General Janos Damjanich, in March he was vested in the command of the division of the III Hungarian Army Corps (6 battalions of honveds, the 2 nd Polish battalion, 4 volunteer infantry rifle companies, 4 squadrons of hussars from the 2nd Hannover regiment, a regiment of Władysław Poniński's uhlan lancers and 3 artillery batteries $)^{27}$.

The Legion under the direct command of Captain Ignacy Czernik, expanded to more than 600 men, consisted of 5 companies (reinforced with 2 companies from the former riflemen regiment of Henryk Rembowski, under the command of Antoni Wieruski at that time, and the company under the command of Hipolit Żołtkowski from the Upper Hungary battalion of Idzikowski) and during the spring campaign ended up in one of the finest divisions of the insurrectionist army - the 2-brigade division of Wysocki in Damjanich's corps ${ }^{28}$. The Polish battalion, the 3rd battalion of the 60th regiment of Waza and the 42nd battalion of honveds formed the brigade of Colonel Ede Czillich and the brigade of Major Karoly Leiningen-Westerburg consisted of the 3rd battalion of the 19th regiment of Schwarzenberg and the 3rd battalion of honveds reinforced with 3 units from the 3rd regiment of hussars and a Polish unit of uhlan lancers.

\footnotetext{
23 L. Russjan, Polacy i sprawa, p. 48; E. Kozłowski, Legion Polski, p. 175; B. Szyndler, Henryk Dembiński 1791-1864, Warszawa 1984, p. 272; G. Klapka, Der Nationalkrieg, vol. 1, p. 207; A.F. Danzer, Dembiński In Ungarn, Vienna 1873, vol. 1, pp. 108-109.

24 Zygmunt Jordan (1824-1866), PSB, vol. 11, Kraków 1964-1965, pp. 290.

25 E. Kozłowski, Legion Polski, p. 181; A. Danzer, Dembiński in Ungarn, vol. 1, p. 100; A. Jeziorański, Pamiętniki, vol. 1, p. 52-53; I. Grabowiecki, Moje wspomnienia, p. 167.

26 E. Kozłowski, Legion Polski, pp. 188-194; B. Szyndler, Henryk Dembiński, pp. 273-275; J. Bułharyn, Rys wojny, p. 140, pp. 159-160; G. Klapka, Der Nationalkrieg, vol. 1, p. 249; A. Danzer, Dembiński in Ungarn, vol. 1, pp. 89-90, pp. 179-180; A. Jeziorański, Pamiętniki, vol.1, pp. 56-57; J. Wysocki, Pamiętnik, pp. 37-38; I. Grabowiecki, Moje wspomnienia, pp. 169-170; A. Grochowalski, Kampania na Wegrzech, pp. 330-332.

27 A. Kozłowski, Legion Polski, p. 104; A. Szmyt, Generał Józef Wysocki, p. 141; J. Bułharyn, Rys wojny, p. 194; W. Poniński, Wspomnienia, p. 39.

28 According to Wysocki himself the formation received honorary distinctions for valour.
} 
The Poles distinguished themselves during the spring offensive of the revolutionary state of Hungary. In Szolnok (5th of March 1849) the III Corps provided the decisive support to the division of Colonel Karoly Vecsey fighting against the forces of General Franz Ottinger. Brigadier Wysocki was in command of the right flank of the battle line (a Polish battalion, 3 battalions of honveds, a battalion of a line infantry from the 60th Waza regiment and the 19th regiment of Schwarzenberg) ${ }^{29}$. The attack on the town, in which Wysocki participated, opened with the assault of the Polish battalion followed by the remaining units. The most glorious event during the battle turned out to be the charge of the 120 -men strong unit of Poniński's lancers on the 11th regiment of Franz Jozsef's dragoons (2 divisions of dragoons, riflemen infantry and artillery) covering the retreat of the imperial army which gradually inspired Hungarian cavalrymen to follow ( 2 units from the 2 nd regiment of hussars and a unit from the 3rd regiment of hussars followed by the other two units from the 2nd hussars regiment). Lieutenant Józef Jagmin was the commander of the infantry platoon which captured a bridge on the Cisa river, which facilitated the further pursuit ${ }^{30}$. The general retreat of the enemy made the assault on Buda and Pest possible. Apart from five Polish officers awarded with the Order of Merit, third class, Wysocki was promoted to the rank of colonel.

Near Hatvan (2nd of April), while providing help to the VII Corps of General Andras Gaspar fighting against the III Corps of Schlick, brigadier Wysocki displayed, against the official directives, clarity of mind. Due to his actions Austrians were stopped and as a result of General Gaspar's and Wysocki's battalion counterattack, the hill and the town were retaken ${ }^{31}$. Jagmin, leading an improvised assault unit and accompanied by Zygmunt Miłkowski, displayed insane bravery despite being under fire of the Austrian artillery utilising canister shots ${ }^{32}$. Commanding the leading platoon and followed by the Polish companies of infantry he led the attack across the beams of broken spans and captured the bridge on Zagyva. He took position far beyond the bridge and refused to leave the beachhead, an act for which he was temporary arrested.

Near Tapiobicske (4th of April), during the meeting engagement between the corps of General Klapka and the infantry brigades of General Daniel Rasztich and cavalry from the I Corps of ban Jelacic led by colonel Leopold Sternberg, the victory of Hungarians enabled Damjanich to bring over his corps while the Poles from the division of Wysocki, which took over the brunt of fighting (the 3rd battalion of the 19th infantry regiment, the 3rd battalion of the 60th infantry regiment and two battalions of honveds entered combat) were able to capture the bridge on the Tapio river and the entirety of the dike during the counter-assault. A unit of Poniński's uhlan lancers was among the units participating in the pursuit ${ }^{33}$.

\footnotetext{
29 E. Kozłowski, Legion Polski, p. 206; according to A. Szmyt J. Wysocki was in command of the first line of the insurrectionist units.

30 E. Kozłowski, Legion Polski, p. 206-209; I. Kovacs, Nieznani polscy bohaterowie, p. 49, 139; A. Szmyt, Generat Józef Wysocki, pp. 149-150; J. Bułharyn, Rys wojny, pp. 95-98, p. 194, pp. 200-201; A. Jeziorański, Pamiętniki jenerała, pp. 60-62; J. Wysocki, Pamiętnik, p. 39; W. Poniński, Wspomnienia, pp. 42-43; K. Kalita, Ze wspomnień, „Biblioteka Warszawska”, 1912, pp. 241-242; Z. Miłkowski, Od kolebki, vol.1, pp. 296-297.

31 E. Kozłowski, Legion Polski, p. 211-212; J. Wysocki, Pamiętnik, pp. 47-48; Z. Miłkowski, Od kolebki, vol.1, pp. 303-304.

32 S. Kieniewicz, M. Małecki, Zygmunt Miłkowski (1824-1915) ps. Tomasz Teodor Jeż, PSB, vol.10, Kraków 1963

33 E. Kozłowski, Legion Polski, p. 212-213; A. Szmyt, Generał Józef Wysocki, pp. 153-154; T. Bułharyn, Rys wojny, pp. 228-229; J. Wysocki, Pamiętnik, p. 49; W. Poniński, Wspomnienia, pp. 46-47; Z. Miłkowski, Od kolebki, vol. 1, pp. 305-306; A. Grochowalski, Kampania na Wegrzech, p. 347.
} 
Near Isaszeg (6th of April) the Hungarian corps, continuing the pursuit, caught up with the enemy: Klapka attacked the right flank of Jelecic's corps while Damjanich attacked the left wing utilising the division of General Karoly Knezić whereas the division of Wysocki remained in reserve. Subordinates of Wysocki stopped the unexpected attack in the forest on the rear of Schlick's corps (the so called Royal Woods) initially with the forces of the Waza battalion led by captain Adam Hoszowski, later with the aid of Leiningen's brigade and, finally, with the newly arrived corps of General Lajos Aulich, and thus enabled General Klapka to repel the enemy ${ }^{34}$. It was the most significant victory of the spring campaign. During the parade of the triumphant army in front of Kosstuth, the dictator took of his hat and held it in hand until the division of Wysocki, Polish legionnaires and uhlan lancers in particular, marched through ${ }^{35}$.

In Waców near the Danube river (10th of April) the left-flank formation of Wysocki was to assault the town during confrontation between Klapka's and Damjanich's corps and the division of General Hermann von Ramberg who was replaced by brigadier General Christian Gotz (killed by the Poles during the battle) and, later, by brigadier General Feliks Jabłonowski. The pivotal event during the battle was the assault on the stone bridge spanning over the Gombas stream, which included the major episode of capturing the legion banner from the hands of falling soldiers. This very banner was later presented to the Minister of War on request of General Gorgei to receive the Distinguished Service Order, third class. A Polish battalion scattered the Austrian artillery crews and later resisted the charge of cavalry. The commander in chief of the Habsburg army, Fieldmarshal Alfred zu Windischgraetz, was deposed for being defeated ${ }^{36}$.

Under the orders of the commander of the corps Colonel Wysocki was to take over the command of the insurrectionist forces during the first stage of the battle in Nagysallo (19th of April). The III Corps including the division of Wysocki was located in the centre, initially General Damjanich remained outside the area of the battle and the VII Corps of General Gaspar came late to their positions on the left flank. Since the I Corps of Klapka pushed the enemy out of Nagysallo, Wysocki made an attempt to support Klapka's actions and as a result he captured the very village ${ }^{37}$. They were able to effortlessly stop the assault of imperial battalions. According to some of the sources, the Poles were first to launch a bayonet charge and according to others they displayed great merit during fights in the streets. As a result of the battle the Danube fortress of Komarno was captured (22nd of April).

After crossing the Danube river via a pontoon bridge the division of Wysocki participated in repelling the enemy from the area surrounding Komarno fortress (27th of April) by the army of General Gyorgey (divisions of Knezich, Wysocki and Klapka) and in the following

34 E. Kozłowski, Legion Polski, p. 214-215; A. Szmyt, op. cit., pp. 154-155; J. Szyc, Legiony polskie, p. 34, pp. 36-37, p. 45; J. Bułharyn, Rys wojny, pp. 232-232; A. Jeziorański, Pamiętniki jenerała, p. 65; J. Wysocki, Pamiętnik, pp. 51-52; Z. Miłkowski, Sylwety emigracyjne, Lwów 1904, p. 130; idem, Od kolebki, vol. 1, pp. 306-207. A literary description of the battle can be found in "Lalka [The Doll]" by Bolesław Prus.

35 E. Kozłowski, Legion Polski, p. 209, p. 215; K. Kalita, Ze wspomnień, p. 243.

36 E. Kozłowski, Legion Polski, p. 217; I. Kovacs, Polacy w węgierskiej Wiośnie Ludów, pp. 406-408; A. Szmyt, Generał Józef Wysocki, p. 155; J. Szyc, Legiony polskie, p. 39; J. Bułharyn, Rys wojny, p. 235; J. Wysocki, Pamiętnik, p. 53; W. Poniński, Wspomnienia, p. 47.

37 A. Szmyt, Generat Józef Wysocki, pp. 157-158; E. Kozłowski, Legion Polski, pp. 218-219 - according to him Damjanich was constantly present; I. Kovacs, Polacy $w$ węgierskiej Wiośnie Ludów, p. 412; G. Klapka, Der Nationalkrieg, vol. 1, p. 241; Z. Miłkowski, Od kolebki, vol. 1, p. 313; J. Wysocki, Pamiętnik, pp. 58-61. 
pursuit which led them as far as Gyor on the road to Vienna, in which uhlan lancers of Poniński also participated ${ }^{38}$. The seventh victory of the Polish Legion has been recorded: This modest unit could not turn the tide of war but at times the bravery of Polish infantrymen and uhlan lancers decided the outcome of a battle ${ }^{39}$. Next the battalion of Czernik and the unit of Poniński were performing the auxiliary service during the siege of Buda, but did not participate in the general assault and were sent back to Miszkolc ${ }^{40}$.

Owing to the contributions discussed hereinabove Wysocki was promoted to the rank of general and received the command of all the Polish units in Hungary dispersed in corps fighting against the Habsburg military forces (9th of May) ${ }^{41}$. The main Polish formation was organised in Miszkolc. In June the Legion consisted of 4 battalions of infantry, 2 regiments of uhlan lancers (each consisting of 3 squadrons) and an engineering company ${ }^{42}$. Up to two thousand three hundred-five volunteers served in infantry, 560 men served in cavalry, approx. 75 individuals served in the artillery units and approx. 80 men in an additional small unit, approximately 3 thousand legionnaires in total. The Legion was attached to the division of Tadeusz Bułharyn (19th Armee-Division consisting of two brigades) in the IX Corps of General Henryk Dembiński ${ }^{43}$.

Special committees supporting Magyars were operating in two largest cities of Galicia and had branches in smaller towns. The operation of smuggling volunteers proceeded along the established trails with the developed network of rally points and staging areas as well as with the help of guides operating in the borderlands. The attempts at breaking through the border were usually made in small groups consisting of dozen or so to several dozen individuals ${ }^{44}$. The recruitment to the Legion of Wysocki yielded results and Polish and Ukrainian captives and prisoners of war were enlisted. Notwithstanding that, fratricidal skirmishes between infantrymen from the 9th, 10th, 12th, 40th and 58th regiments took place ${ }^{45}$.

Karol Kalita was a deserter ${ }^{46}$. He served in the 9th infantry regiment from Stryj, consisting chiefly of Polish recruits and had been preparing for expedition to Hungary since December 1848 but he was granted a leave of absence in order to continue studying. The ultimate reason behind his escape was supposed to be a pin with the symbol of a white eagle

38 I. Kovacs, Polacy w węgierskiej Wiośnie Ludów, p. 417; A. Szmyt, General Józef Wysocki, pp. 158-159; E. Kozłowski, Legion Polski, pp. 220-221; J. Szyc, Legiony polskie, p. 44; A. Jeziorański, Pamiętniki jenerała, p. 67; W. Poniński, Wspomnienia, p. 48; Z. Miłkowski, Od kolebki, vol. 1, p. 318.

39 E. Kozłowski, Legion Polski, p. 221.

40 E. Kozłowski, Legion Polski, p. 221; Z. Miłkowski, Od kolebki, vol. 1, p. 319.

41 E. Kozłowski, Legion Polski, p. 136, 144; I. Kovacs, Polacy w węierskiej Wiośnie Ludów, pp. 477-478; A. Szmyt, Generał Józef Wysocki, pp. 161-162; J. Wysocki, Pamiętnik, p. 65.

42 E. Kozłowski, Legion Polski, p. 141-145; I. Kovacs, Nieznani polscy bohaterowie, p. 53.

43 E. Kozłowski, Legion Polski, p. 223-225.

44 L. Russjan, Polacy i sprawa, p. 90; E. Kozłowski, Legion Polski, pp. 45-48, pp. 54-58; P. Wodziński, Wspomnienia, p. 9, p. 16; Z. Miłkowski, Od kolebki, p. 271; I. Grabowiecki, Moje wspomnienia, pp. 141-142; J. Rucki, Opowiadanie officera.., „Dziennik Polski”, Poznań 1849, no. 155; idem, Z pamiętników żołnierza, p. 393; A. Jeziorański, Pamiętniki, vol. 1, pp. 3-4, p. 20; W. Poniński, Wspomnienia, p. 26; J. Sokulski, W kraju i nad Bosforem, Wrocław 1951, p. 192; S. Łusakowski, Pamiętniki zdeklasowanego szlachcica, Warszawa 1952, p. 192.

45 E. Kozłowski, Gen. Józef Bem, pp. 470, p. 473; idem, Legion Polski, pp. 166-167, pp. 284-285; M. Baczkowski, Galicjanie w armi austriackiej wobec wydarzeń lat 1848-1849, in: Galicja i jej dziedzictwo, vol. 12, Galicja w 1848 roku, editor W. Bonusiak, J. Buszko, Rzeszów 1999, p. 94-95; Geschichte des k.u.k. Infanterie,-Regiment Erherzog Wilhelm no. 12, vol. 2, Wien 1880, pp. 202-205, pp. 272-276.

46 L. Ratajczyk, Karol Kalita ps. Rębajło (1830-1919), PSB, vol. 11, Kraków 1964-1965, vol. 11, p. 41. 
attached to his tie spotted by an officer of customs service. With the help of the recruitment committee in Jarosław he crossed the Galician cordon near Łupków in the beginning of May 1849, evaded the Landsturm units and went to Miszkolc where he enlisted in the 3rd squadron of the 1 st lancer regiment ${ }^{47}$. Zygmunt Miłkowski along with 11 companions was also able to come to Hungary due to the support received from a network of committees, with the committee in Lviv providing the initial help. The godfather of the Polish national movement began his career as a second lieutenant in the 3rd battalion. One of the members of the Legion organisational commission was lieutenant Franciszek Ksawery Horodyński ${ }^{48}$, the commander of the 1st company of the 3rd battalion.

Jeziorański served as an aide de camp in the reorganised 2nd battalion of Wieruski. Walery Lewandowski, who escaped to Hungary wishing to avoid persecution for his actions as a member of the National Council in Rzeszów, was appointed as a second lieutenant of an artillery battery and in the last days of fighting he saved several Russian prisoners of war, including Captain Nikolai Drejer, from lynching ${ }^{49}$. Walery Kozłowski was also a member of Wysocki's legion ${ }^{50}$.

In the 2nd regiment of legion lancers of Lieutenant Colonel Władysław Tchórznicki we can come across cavalry Captain Wiktor Dunajewski, brother of Edward Dunajewski. Both of them escaped from Galicia to Hungary and it can be conjectured that Edward served with his brother in the same unit ${ }^{51}$.

Józef Wysocki was promoted to the rank of brigadier general (3rd of June), and after dismissal of General Dembiński ${ }^{52}$, took over command of the Northern Army consisting of the IX Corps of honveds, the reserve division of second Lieutenant Lajos Kazinczy, the mobile unit of Major Armin Gorgey and the Polish Legion. The Polish formation consisted of 3 infantry battalions, each consisting of 5 companies (4 line companies and a rifle company, 800 men in total), 2 regiments of uhlan lancers, each consisting of 4 squadrons, 2 artillery half-batteries and an engineering company ${ }^{53}$.

Soon Wysocki was appointed to the station of Obercommandant of the IX Corps and the independent division of Kazinczy, which apart from leading the operations directly involved regularly issuing dispositions to Generals Aristid, Dessewffy and Kazinczy, and preparing regular reports ${ }^{54}$. Instead of opposing the enemy in the area of Preszów on the 22nd of June he made the decision to initiate a fighting retreat before the forces of Imperial intervention corps (II, III and IV corps) encroaching into the Hungarian territory through the Carpathian

47 K. Kalita, Ze wspomnień, p. 244.

48 Franciszek Ksawery Horodyński (1811-1863), PSB, vol. 10, Kraków 1963, p. 3; E. Kozłowski, Legion Polski, pp. 146-147; J. Wysocki, Pamiętnik, p. 145.

49 M. Tyrowicz, Walenty Lewandowski (1824-1916), PSB vol. 18, Kraków 1973, pp. 211-213; I. Kovacs, Nieznani polscy bohaterowie, p. 183; J. Wysocki, Pamiętnik, p. 145.

50 J. Wysocki, Pamiętnik, p. 149.

51 M. Tyrowicz, Edmund Dunajewski (?-1863), PSB, vol. 6, Kraków 1947, p. 465; A. Zieleniecki, D. Kacnelson, Udział Polaków z Galicji w powstaniu węgierskim 1848-1849 r., „Rocznik Naukowo-Dydaktyczny Wyższej Szkoły Pedagogicznej w Rzeszowie”, 1982, p. 71; I. Kovacs, Polacy w węgierskiej Wiośnie Ludów, p. 384; J. Wysocki, Pamiętnik, p. 147.

52 B. Szyndler, Henryk Dembiński, p. 281-282.

53 E. Kozłowski in: Zarys dziejów wojskowości polskiej do 1864 r., vol. 2, part 2, p. 473; idem, Legion Polski, pp. 134-135, pp. 237-238; A. Szmyt, Generał Józef Wysocki, p. 166.

54 E. Kozłowski, Legion Polski, p. 247. 
Mountain passes. The forces at the disposal of Wysocki (2 rifle battalions of Major Lajos Cornidesz, 9 battalions of honveds, the 2 nd battalion of the Polish Legion, the battalion of Lajos Beniczky, 12 companies of volunteers formed into 2 battalions, the special unit of A. Gorgey, 6 squadrons of hussars, a squadron of uhlan lancers from the 2 nd regiment, a squadron of the National Guard, 31 cannons and 3 pieces of rocket artillery) were, along with the division of Kazinczy, estimated to have enlisted approx. 21 thousand soldiers. The Russian II Corps of General Paweł Kuprianowicz and the IV Corps of General Michaił Czeodajew, forces directly threatening Wysocki, consisted of 80 battalions of infantry, 64 squadrons of cavalry and 12 "sotnia" units of Cossacks - 71 thousand infantrymen, 9.5 thousand cavalrymen and 288 cannons which translated into fourfold numerical advantage in terms of men and fivefold numerical advantage in terms of artillery. The planned defence in the area of Koszyce was made impossible by the enemy's attempt at flanking, which forced Wysocki to fall back further. The Obercommandant initiated actions stalling the march of the intervention forces and concurrently attempted to preserve headcount endangered by the risk of relaxation of discipline and the risk of desertion from ranks ${ }^{55}$. Eligiusz Kozłowski noticed that Wysocki, lacking commanding competences on the operational level, had been constantly retreating over the period of 2 weeks and the distance of $250 \mathrm{~km}$ which resulted in surrendering spreads of the Hungarian land without a fight and in 1/4 of casualties ${ }^{56}$. Wysocki was acting in accordance with the directives of Gorgei, the Minister of War, as confirmed by a representative of the staff of commander-in-chief Paskiewicz: to engage in battle only with equal forces, otherwise feign operational readiness and continue retreating. The safest course of action missed the expectations of Kossuth who hoped to stop Russians.

The Polish general unsuccessfully attempted to establish communication with his higherrank seniors, Bem and Dembiński, as well as with the commander of the IV Corps, General Mor Perczel ${ }^{57}$. The IX Corps stopped in Cegled, where its commander attempted to join forces with the V Corps of General Antal Vetter (6th of July). After the failed attempt at resigning from his position Wysocki continued the retreat of the Upper Hungary Army towards Szegedyn with the Polish Legion acting as rearguard. Wysocki was forced to temporarily subject to the command of General Perczel, the commander of Tisza Army (the Polish Legion, the IX Corps, the X Reserve Corps) guarding the centre of the line on the Cisa river against Russians.

A cavalry formation ( 3 squadrons from the 5 th regiment of hussars, 4 squadrons from the 17 th regiment of hussars, a regiment of hussars from Karoly's regiment, 2 squadrons from the Mikołaj and Palatyn regiment, a towed battery of 6-pound cannons, 2 small regiments of Polish uhlan lancers and a Polish Legion half-battery of 3-pound cannons - 1800 hussars and 600 Polish uhlan lancers) under the formal command of General Lazar Mesaros, carrying out a reconnaissance of the communication line of the main Russian army, engaged in the battle in Tura (20th of July) with the cavalry of General Aleksander Tołstoj (Elisavetgrad

55 A. Szmyt, Generat Józef Wysocki, p. 169; E. Kozłowski, Legion Polski, pp. 244-246, p. 255.

56 E. Kozłowski (Legion Polski, p. 257, p. 259, p. 261, p. 262) suggests that Russians, having overestimated his forces, did not plan on pursuing; token resistance in Cernevicsa 19 VI, in Lemes-Somos $23 \mathrm{VI}$ - lietenant W. Ramming, Der Feldzug in Ungarn und Siebenburgen in Januar 1849, Pest 1850, p. 176; J. Bułharyn, Rys wojny, p. 284; A. Danzer, Dembiński in Ungarn, vol. 2, p. 89; J. Wysocki, Pamiętnik, p. 87; N. Scerbatov, General feldmarsal knjaz Paskevic, ego zizn i dejatelnost, St. Petersburg 1899, vol. 5, pp. 148-184, vol. 6, pp. 87-88, p. 93.

57 W. Ramming, Der Feldzug, p. 184; E. Kozłowski, Legion Polski, p. 264. 
regiment of Grand Duchess Olga, 5 squadrons from the 4th regiment of the king of Hannover, 2 squadrons from the Charkov regiment of lancers, 2 ,sotnia” units of Cossacks, 2 towed artillery batteries) in the sole cavalry battle of the entire war. The Russians were slightly more numerous and possessed more cannons of a larger calibre. The Polish regiments formed the right flank, tied Hanover hussars in combat and stood fast under the barrage of enemy artillery $^{58}$. The confusion among the Russian ranks caused by the Hungarian hussars was stopped by the arrival of the 5th division of infantry of General Ivan Labincov along with a battery of heavy towed artillery. Karol Kalita fought in this battle as a private individual in the regiment of the Legion uhlan lancers. Despite the defeat the battle resulted in stopping the Russian high command from sending its main forces against the Hungarian army retreating from Waców ${ }^{59}$. At the turn of July and August of 1849 General Wysocki in command of the IV and IX Corps infantry led their retreat from Szegedyn ${ }^{60}{ }^{61}$

General Henryk Dembiński, once again in command of the entirety of the insurrectionist forces which in actuality consisted of the Southern Army with units concentrated around Szegedyn and scattered across Bačka and Banat (36.5 thousand men and 87 cannons), ordered to retreat without engaging the enemy due to the paucity of the military potential of his forces and the fact that the I Corps of Schlick crossed the Cisa river and the III Corps of ban Jelacic was approaching from south of Szegedyn ${ }^{62}$.

The Polish legionnaires defending the crossing on the Cisa river near Szoreg counterattacked (4th of August). Zygmunt Jordan, stationed with 2 companies of infantrymen and 2 cannons in the bridge beachhead in the fork of the Cisa and Marusza rivers, was preventing the group of General Julius von Haynau from landing ${ }^{63}$. The 10th platoon under the command of second Lieutenant Zygmunt Miłkowski forced the raft bearing Austrians to retreat and most probably injured General Ludwig von Benedek, Fieldmarshal Franz Liechtenstein and Franz Codon, a former Minister of War, who were leading the vanguard of the enemy (4 companies of riflemen, a battery of rocket artillery) ${ }^{64}$. Although Dembiński reinforced Jordan's forces by Czernik's battalion and directed the IX Corps to the dyke because of a heavy artillery barrage and a fierce push of the enemy, he was forced to order main forces to retreat ${ }^{65}$. Jordan was left with only a handful of men and without support was unable to stop the enemy from building a bridge and crossing the river. According to B. Szyndler, the Austrians built a bridge on the Marusza river and thus threatened defenders with encirclement. In Szoreg 2 divisions of infantry and 40 cannons were defending against all-out attacks and artillery barrage. An attempt was made at charging the enemy with units of hussars and the Polish

\footnotetext{
58 I. Kovacs, Nieznani polscy bohaterowie, pp. 143-144; J. Bułharyn, Rys wojny, pp. 305-306; K. Kalita, Ze wspomnień, p. 246; W. Poniński, Wspomnienia, p. 53.

59 I. Kovacs, Nieznani polscy bohaterowie, pp. 142-144.

60 E. Kozłowski, Legion Polski, p. 276; I. Grabowiecki, Moje wspomnienia, p. 185.

${ }^{61}$ Generals Dembiński, Dessewffy and Perczel were also present. J. Bułharyn, Rys wojny, p. 304; A. Danzer, Dembiński in Ungarn, vol. 2, p. 130-136; W. Poniński, Wspomnienia, p. 31; J. Grabowiecki, Moje wspomnienia, p. 183.

62 E. Kozłowski, Legion Polski, p. 277; B. Szyndler, Henryk Dembiński, p. 285; W. Zamoyski, Jenerat Zamoyski 1803-1868, Poznań 1930, vol. 5, pp. 242-243; S. Schnur-Pepłowski, Polacy i Wegrzy, p. 266.

63 E. Kozłowski, Legion Polski, p. 278.

64 E. Kozłowski, Legion Polski, p. 277; Z. Miłkowski, Od kolebki, vol. 1, pp. 346-349.

65 B. Szyndler, Henryk Dembiński, p. 281; A. Jeziorański, Pamiętniki jenerała, p. 182.
} 
uhlan lancers but after Dembiński had been crushed under an injured horse, a retreat from the flood embankment and the dyke near Nowy Segedyn began (5th-7th of August) during which the Polish cavalry of Poniński played significant role ${ }^{66}$.

On the 7th of August General Józef Bem was appointed to the position of the commanderin-chief of the Hungarian Armed Forces. Instead of marching to Arad, the residence of the revolutionary government, the army headed towards Temesvar where the decisive battle of the insurrection took place (9th of August 1849). The revolutionary army (the IV Corps of General Richard Guyon, the IX Corps of Wysocki/Dessewffy consisting of approx. 10 thousand men and 20 cannons located in the middle of the front line; the X Corps of Colonel Gall and General Kmetty and the part of the V Corps of Vecsey held in reserve and serving as the rearguard) comprised of approx. 55-60 thousand soldiers and 100-164 cannons clashed with 28-30 thousand-men strong coalition forces of General Julius von Haynau (the III Corps of General Georg Ramberg, the IV Corps of Duke Franz Lichtenstein, the cavalry division of General Karl von Gimborn-Wallmoden, the Russian division of General Fiodor Panjutin, 194 cannons $)^{67}$. The battle opened with a strong barrage of the Hungarian artillery stationed in the middle of the front line. Eight squadrons of hussars from the corps of General Kmetty attacked with the intention of flanking the enemy from the south. At that time General Haynau utilised the reserve artillery and the division of General Paniutin to perform a frontal assault on the corps of General Dessewffy. On the right Hungarian flank, the corps of General Guyon, was encircled by the division of General Anton Herzinger and the brigade of General Eduard Siegenthal. The Polish Legion was located on the right flank of the IX Corps, a half-battery of towed artillery was set up in the middle with the 3rd battalion under the command of one of the company chiefs, Franciszek Horodyński, who supplanted ill Władysław Englert, placed to the left, near a stone bridge; two regiments of lancers engaged in a fight with the regiment of Schwarzenberg ${ }^{68}$. The defence of the Marad-Temesvar road near Szentadras continued to the last man. The Legion infantry covered the Hungarian infantry and held back the push of 3 Russian squadrons supported by artillery. During this stage of campaign, Jordan, promoted in recognition of his contributions to the defence of the beachhead on the Cisa river and the battle in Temesvar to the rank of major and presented with the Order of Merit, second class, became the aide-de-camp of the commander-in-chief. Captain Józef Jagmin also became one of the dozen or so cavaliers of the Order of Merit.

Not all the Poles engaged in military actions in Hungary ended in the formation of Wysocki. Let us recall General Józef Bem and in the annals of heroic fight of Magyars for national liberation we will uncover compatriots assisting the Polish general. General Bem, the hero of Ostrołęka and Vienna, received nomination for the position of the commander of the armed forces of Transylvania on the 29th of November $1848^{69}$. During the winter campaign (18th of December 1848 - 26th of March 1849) Bem commanded approx. 12.5 thousand-men

66 B. Szyndler, Henryk Dembinski, p. 285-286.

67 Not taking into account the unengaged corps of Schlick. E. Kozłowski, Gen. Józef Bem, pp. 564; idem, Legion Polski, p. 283; W. Ramming, Der Feldzug, pp. 343-344; p. 347; R. Kissling, Die Revolution im Kaisertum, vol. 2, p. 258 .

68 E. Kozłowski, Legion Polski, p. 283-285; idem, Gen. Józef Bem, pp. 564-567; W. Poniński, Wspomnienia, p. 58, p. 61; J. Wysocki, Pamiętnik, pp. 122-123; A. Jeziorański, Pamiętniki jenerała, pp. 84-87; Z. Miłkowski, Od kolebki, vol. 1, p. 355.

69 E. Kozłowski, Gen. Józef Bem, pp. 294. 
strong Army of the Upper Transylvania (the 1st brigade of Major Ignac Riczko - 1400 regular army soldiers, 3 thousand guardsmen, 75 cavalrymen and 6 cannons; the 2nd brigade of Lieutenant Colonel Janos Czetz - 1650 line infantrymen, 1900 guardsmen, 900 riders and 10 cannons and the 3rd brigade under his own command - 2300 line infantry, 900 guardsmen, 410 cavalrymen and 8 cannons). Austrian Fieldmarshal Anton Puchner commanded 11 battalions of line infantry, 7 battalions of borderlands infantry and 16 squadrons of cavalry (13,650 men and 18 cannons) and, although he could have been resorting to the help of Romanian guerrilla fighters, in actuality he was in command of 15-16 thousand soldiers ${ }^{70}$. Narcyz Figietty, a participant of the campaign in Transylvania, and Władysław Józef Rucki (Drucicki), who escaped to Hungary after the events of 1846 in Galicia and initially served in Transylvanian units of honveds and later moved to the Polish Legion of Transylvania, after being promoted to second lieutenant, served among other volunteers in Bem's forces ${ }^{71}$.

The military struggles which lasted dozen or so weeks proceeded as follows: on the 18th of December Austrian Colonel Urban accompanied by General August Wardner clashed in the battle of Csucsa with the brigade of Major Riczko ${ }^{72}$. The Austrian assault against the brigade of Czetz took place near Zsibo and Szurduk (19th - 20th of December) and brigades of Bem began operations in the area of Des (22nd of December). The capture of Kolozsvar/ Cluj, the capital of the Transylvania region, by General Bem (25th of December) concluded the first stage of the campaign ${ }^{73}$.

On the 2nd of January 1849 Bem entered the town of Beszterce (Bistrica, Bystrzyca) and pushed Urban behind the line of the Carpathian Mountains after the battle near Tihuca, which took place on the following day and even managed to launch a sally on Bukowina ${ }^{74}$. On the 13th of January the commander found himself in Marosvasarhely, the main canter of Székelys, the Hungarian highlanders from the northern-east of Transylvania ${ }^{75}$. On the 17th of January Bem was victorious in the battle of Galfalva ${ }^{76}$ and later "apo Bem" marched on the second capital of Transilvania, Sybin (Nagyszeben), where he fought in the battle with Puchner and was forced to retreat (21st of January $)^{77}$.

The Hungarians began to lose the initiative: they still managed to rout the Austrian brigade of General Kalliani (24th of January) in the battle near Szelindek ${ }^{78}$ but on the 4th of February the Austrian-Russian task force (more than 8 thousand soldiers) managed to defeat 3 thousand Hungarian enemies and between the 5th and 7th of January, during the fighting in the area of Szaszsebes and Szaszvaros, the brave assault of Hungarians ended in an orderly retreat;

\footnotetext{
70 Ibidem, pp. 325-330.

71 J. Sokulski, Władysław Józef Rucki (Drucicki) (1815-?), PSB, vol. 5, Kraków 1939-1946, pp. 397-398. The Transylvanian Legionwas described in historiography by, among other authors, E. Kozłowski (Gen. Józef Bem, pp. 469-475), J. Grobicki (Formacje kawalerii polskiej na obczyźnie po roku 1831, „Przegląd Kawaleryjski”, 1927, pp. 423), as well as D. Kacnelson and I. Kovacs, Pamiętniki Edmunda Ślaskiego a legion polski w Siedmiogrodzie, „Akcent”, no. 2-3, 1992, pp. 316-330.

72 E. Kozłowski, Gen. Józef Bem, pp. 337-340.

73 Ibidem, p. 344-347.

74 Ibidem, p. 351-357.

75 Ibidem, p. 366.

76 Ibidem, p. 367-372.

77 Ibidem, pp. 372-381.

78 Ibidem, pp. 383-387.
} 
the ten-fold numerical advantage of imperial forces became painfully obvious ${ }^{79}$. The tides turned during the battle of Piska near the Sztriga river (9th of February). The brigades of Czetz and Kemeny (approx. 2 thousand infantrymen) fought against the group of Puchner, the division of Kalliany and Romanian guerrilla fighters (approx. 7 thousand soldiers). It was when Bem uttered his famous words: We have lost the bridge, we have lost Transylvania. When the Austrians crossed to the western bank of the river they were assaulted by Czetz and the battalion of Mariassy, Bem cut of the retreat with the artillery fire zeroed in on the bridge, ordered honveds to attack and recaptured the bridge and forced Puchner to retreat ${ }^{80}$. The victor captured Medgyes in stride (10th of February).

Towards the end of 1848, after the capture of Kolozsvar, the organisational work began to form a Polish Legion consisting of Polish volunteers from Galicia, legionnaires conflicted with Wysocki or not accepted previously as well as the Austrian and Russian prisoners of war supplemented with Ukrainians, Slovaks and Romanies. They were moved to the town of Beszterce located near the border with Galicia ${ }^{81}$. Towards the end of January the unit contained 200 men and before the spring offensive it grew to be nearly 400 -men strong ${ }^{82}$.

The retreat of the brigade of Colonel Riczka (the 3rd battalion of the "Sandor" regiment, the 32nd battalion of honveds, 4 companies of the Polish Legion, cavalry - 2 squadrons of hussars, elements of Polish cavalry, 6 pieces of light artillery - approx. 1500 men) ${ }^{83}$ during the offensive (11th - 17th of February 1849) launched by the elements of corps of Colonel Karol Urban and General Ignac Malkovski (7th company of infantry, a squadron of cavalry, a half-battery of artillery and a battalion of infantry - approx. 1300 soldiers), which involved the decisive battle of Kiralynemeti and the fighting retreat near Szeretfalva, was accounted for by the Polish infantry units ${ }^{84}$. They participated in the counteroffensive designed by Bem who was commanding 2 battalions of honveds, 3 battalions of Székelys, 4 squadrons of hussars and 4 cannons (23rd - 27th of February 1849), during which he forced Colonel Urban to accept battles in Zsoszeny and Borgoprund (26th of February) and to retreat from Transylvania ${ }^{85}$. On the 2nd of March the inconclusive battle between Czetz and Bem took place, both of whom were heading to Segesvar in the attempt to capture and hold the Nagykukullo river line ${ }^{86}$.

Having the command of 10.5 thousand soldiers and 30 cannons, Bem with support of the brigade of Lieutenant Colonel Bethlen launched an assault on Sybin, initiating the second battle for the city (11th of March), against the 5 thousand men-strong garrison of General Skariatin (Russian infantry, 2 Austrian battalions and 2 batteries of artillery, Saxon militia) which concluded with the assault of honveds on the main city gate ${ }^{87}$. The Russian corps

79 Ibidem, p. 399-402.

80 E. Kozłowski, Gen. Józef Bem, pp. 409-417.

81 L. Russjan, Polacy i sprawa polska, p. 131; E. Kozłowski, Generał Józef Bem, p. 473; I. Kovacs, Józef Bem. Bohater wiecznych nadziei, Warszawa 2002, p. 128; W. Rucki, Z pamiętników żotnierza, p. 107.

82 E. Kozłowski, Generał Józef Bem, p. 472; L. Russjan, Polacy i sprawa polska, p. 122, p. 131.

83 E. Kozłowski, Generał Józef Bem, p. 422.

84 F. Bagieński, Wspomnienia starego wołyniaka, Warszawa 1987, pp. 99-100; W. Rucki, Z pamiętników żolnierza, pp. 107-108.

85 E. Kozłowski, Gen. Józef Bem, pp. 474-475.

86 Ibidem, p. 428-433.

87 Ibidem, pp. 437-441. 
retreated to Wallachia, the Saxon and Romanian committees were dissolved and General Puchner was handed in resignation. Braszów was liberated on the 20th of March after Czetz had outmaneuvered General Kalliany ${ }^{88}$. On the 24th of March Bem was appointed as the fieldmarshal and honoured with the Order of Military Merit adorned with a diamond from the national relic of Hungary, the Crown of Saint Stephen.

Over the course of several weeks Bem, among his other actions, intensified the efforts to establish a Polish Legion in Transylvania ${ }^{89}$. His work was hindered by the campaign in Banat (16th of April - 16th of May), which Bem carried out with forces consisting of 8 battalions of infantry, 6-8 squadrons of hussars and 5 battalions of guard. On the 17th of April the battle in Vajszlova against 2 battalions of the Habsburg army was resolved by the actions of the 78th Szekelys battalion. The merging of forces of the corps of General Malkovsky from Wallachia and the Serbian forces of General Teodorovic in Bačka was prevented and after joining forces with General Perczel, the victory was sealed by the liberation of the Banat region with the exception of two strongholds ${ }^{90}$.

With the beginning of July Major Leon Czechowski became involved with reorganisation of the Legion ${ }^{91}$. He came to Hungary towards the end of May or the beginning of June 1849 but he did not receive a proper appointment with the Legion of Wysocki. He got through to the Legion formations in Transylvania where he became a member of the organisational committee led by Lieutenant Colonel Franciszek Salezy Łoś. Promoted to the rank of second lieutenant he was content with the command of the infantry (the 1st battalion and first sub-units of the 2 nd battalion) of the Legion which together with 270 cavalrymen and the crew of field artillery consisted of 900 volunteers ${ }^{92}$. Julian Nadmiller was another incomer from the regiment of Poniński. . It is characteristic that the military discipline there was higher than in Wysocki's units. The camps in Sybina and Beszterce were operational, Samoszujwar became the organisational centre of the Legion cavalry ${ }^{93}$ and the agents of Bem were probing sentiments in Galicia and encouraging local volunteers as the sally to the Carpathian Mountains was expected after the conclusion of the operations in Transylvania. In terms of organisation, the unit was based on the Austrian and Hungarian regulations. White jackets with lapels, collars and shirtcuffs lined with crimson and crimson caps and leggings with white or silver stripe constituted the mandatory uniform ${ }^{94}$. Edmund Ślaski, a member of the Academic Legion from Lviv, was an active supporter of the Hungarian Cause and fought on the barricades in Lviv during the All Soul's Day (2nd of November 1848). He arrived in Hungary on the 20th of June 1849, almost concurrently with the Russian army of

\footnotetext{
88 E. Kozłowski, Gen. Józef Bem, pp. 449.

89 Ibidem, pp. 450-452.

90 Ibidem, pp. 476-485.

91 M. Tyrowicz, Czechowski Leon, PSB, vol. IV, Kraków 1938, pp. 314-315; I. Kovacs, Nieznani polscy bohaterowie, p. 186.

92 E. Kozłowski w Zarysie dziejów wojskowości polskiej do 1864 r., editor J. Sikorski, Warszawa 1966, vol. 1, part 2, p. 471-472, he wrote that the Legion initially consisted of 1300 men formed in an infantry battalion and a cavalry regiment, in July a battalion, a regiment and a half of an artillery battery were restored; I. Kovacs, Józef Bem, pp. 204-20; D. Kacnelson, I. Kovacs, Pamiętniki Edmunda Ślaskiego, p. 329.

93 D. Kacnelson, I. Kovacs, Pamiętniki Edmunda Ślaskiego, p. 325.

94 E. Kozłowski in: Zarys dziejów wojskowości polskiej, p. 474; J. Grobicki, Formacje kawalerii polskiej na obczyźnie, p. 423; J. Szyc, Legiony polskie na Wegrzech, pp. 56-57.
} 
Fieldmarshal Ivan Paskiewicz. He managed to come in time to the Legion of Transylvania, that was being formed at that time, and took over the position of the Secretary of the Board ${ }^{95}$.

In the summer of 1849 the Russian forces in the Transylvanian part of the Crown of St. Stephen consisted of the V Corps of General Aleksander Luders with the support of the detached group of General Gustav Hasford and the Bukowina group of General Magnus Johann Grotenhjelm (approx. 41 thousand infantrymen, cavalrymen and artillery crews). Along with the Austrian soldiers, chiefly from the less engaged corps of General Deurd Clam-Gallas, the allies commanded more than 56 thousand soldiers ${ }^{96}$. On the 19th of August the corps of Grotenhjelm and the Austrian brigade of General Springensfeld (13 thousand infantrymen, 33 cannons) began operations against the "Beszterce" division of Colonel Jozsef Dobay (eight and a half of an infantry battalion, two and a half of a cavalry squadron - 7838 infantrymen and cavalrymen, 12 cannons) and as a result 2 companies of the Polish Legion (465 volunteers) suffered heavy casualties, inclusive of material losses ${ }^{97}$. In Borgoprund (22nd of June) the division fought against the units from the General Grotenhjelm's group and lost, among other casualties, the grievously wounded commander. General Bem arrived with 7 thousand infantrymen and 14 cannons worth of relieving troops $(25$ th -28 th of June $)^{98}$. The reinforced 1st division under the command of Bem launched a counterattack on the pass (26th - 27th of June). After joining forces with the "Beszterce" division his forces successfully opposed the coalition group consisting of 9-11 thousand troops (1st of July) ${ }^{99}$.

On the 10th of July in Beszterce the Legion suffered casualties which reduced the formation to 60 cavalrymen, the decimated 1st battalion and the 2 nd battalion, still at the organisational stage (Rucki served in the 2nd company of the 1st Polish battalion) ${ }^{100}$. It was reinforced with 300 uniformed and armed former prisoners of war sent over from Szegedyn ${ }^{101}$.

By the 21st of July General Bem in command of 8.5 thousand men-strong army (including the Polish legionnaires) and 30 cannons purged the Land of Székelys from the enemies ${ }^{102}$. The local „variation” of the Polish Legion, including Major Tomasz Wierzbicki - one of the officers, made the name for itself.. On the 21st of July the Poles fought bravely in Szaszregen (Reghin) against the forces of the coalition consisting of 7 infantry battalions, 5 squadrons of cavalry, a half of a Cossack ,sotnia” unit and 23 cannons, and despite being threatened with the risk of an attack on the rear lines by the group of General Władysławowicz ( 2 battalions of infantry, 2 squadrons of cavalry, 30 Cossacks, 6 cannons), they managed to force the defenders out while the rearguard formed from 4 Legion companies and 4 cannons destroyed the bridge ${ }^{103}$. As Artur Niepokojczycki, a Russian staff officer of the Polish descent, noted

\footnotetext{
95 E. Ślaski, Pamiętnik z czasów rewolucji węgierskiej 1849 r., „Akcent”, 1992, no. 2/3, p. 331, pp. 342-343.

96 E. Kozłowski, Generał Józef Bem, pp. 503-510.

97 Ibidem, p. 503, p. 509, p. 514; I. Kovacs, Józef Bem, pp. 194-205; A. Niepokojczyckij, Opisanije wojny w Transsilwanii w 1849 g., Petersburg 1858, pp. 301-302, p. 307; W. Rucki, Z pamiętników, p. 171.

98 E. Kozłowski, Gen. Józef Bem, pp. 516-517.

99 Ibidem, Gen. Józef Bem, pp. 519.

100 W. Rucki, pp. 180-181; E. Ślaski, Pamiętnik, pp. 345-346.

101 E. Langie, Pamiętniki niedoli, p. 8.

102 E. Kozłowski, Gen. Józef Bem, pp. 536.

103 Ibidem, pp. 556.
} 
"Polish Legion fought fiercely but our uhlan lancers supported with artillery fire forced them to retreat from their positions every time"'104.

With the forces consisting of 3 battalions of infantry, 2 squadrons of cavalry and a single artillery battery (approx. 2.4-5 thousand soldiers), Bem launched an unexpected raid on Moldova (21st - 25th of July) during which he captured the mountain pass held by a Russian battalion but because he failed to incite locals to take up arms and fight in insurrection he turned back to Transylvania ${ }^{105}$.

After General Aleksander Luders had captured Sybin (16 thousand infantrymen and 50 cannons defeated 8 thousand honveds and 26 cannons), ${ }^{106}$ another battle broke out on the 31st of July in Segesvar (Szekelykeresztur) between 6 thousand of Bem's subordinates and 12 thousand Russians. Since the insurrectionist forces were unable to rally despite the effective artillery barrage which had slain general Skariatin, the relieving troops of general Engelgard, the flanking manoeuvre from the south and the assault of Cossacks from the north broke the defenders. Notwithstanding that, the corps of Luders was unable to join forces of Marshal Paskiewicz and General Haynau. Bem capitalised on the opportunity and assaulted Sybin for the third time with 7.5 thousand infantrymen and 18 cannons and by defeating General Hasdorf's brigade (4.5 thousand soldiers) he claimed the last victory in the scale of the entire revolution (5th of August) ${ }^{107}$. The final battle took place on the 6th of August in Sybin. The hills towering over the buildings were manned with the artillery supported by infantry located in the centre, the retracted flanks of the battle order consisted of cavalry, further infantry and artillery units, a reserve column consisting of 4 cannons and 6 infantry battalions, took position in Nagycsur village, 500 cavalrymen and 18 cannons were facing the V Corps of Luders and the weakened brigade of Hasford. The Russians fended off the attempts at flanking by launching an assault on the left flank and the village. Bem launched an unsuccessful counter-attack and when his left flank was broken by cavalry, the centre of the battle line became exposed. Two Russian battalions launched a frontal assault, broke through the defenders and thus ensured the defeat of insurrectionists ${ }^{108}$. Two cavalry squadrons of the Polish Legion were routed in Kistorony by the Russian cavalry pursuing the defeated $^{109}$. The back of the Transylvania insurrectionist upsurge was broken. Bem handed over command and went to the Northern Great Plain ${ }^{110}$.

On the 13th of August legionnaires were covering the retreat of a part of the Kolozsvar division and the remnants of the Szekelys division from Cluj ${ }^{11}$. Ślaski and Rucki along with the reserve squadron of uhlan lancers participated in the famous charge during the last battle of the northern Transylvania front when the advancing Russian-Austrian division of Grotenhjelm was repelled in Banffyhunyad (16th of August). The lancers from the assault unit

\footnotetext{
104 A. Niepokojczycki, Opisanije wojny, pp. 165-166.

105 E. Kozłowski, Gen. Józef Bem, pp. 539-542.

106 Ibidem, p. 544.

107 Ibidem, pp. 549.

108 Ibidem, pp. 554-558.

109 I. Kovacs, Polacy w węgierskiej Wiośnie Ludów, p. 303; W. Rucki, Ze wspomnień, pp. 203-204, p. 208.

110 E. Kozłowski, Gen. Józef Bem, pp. 553-554.

111 D. Kacnelson, I. Kovacs, Pamiętniki Edmunda Ślaskiego, p. 330; E. Ślaski, Pamiętniki, p. 346.
} 
of Łoś successfully drove off the enemies ${ }^{112}$. The Polish half-battery of artillery remained, as it was customary for Bem, on the forefront and during the retreat, it withdrew last earning respect even among the enemies ${ }^{113}$. The day after the battle Rucki, the commander of the 2 nd company of the 1st battalion, was taken prisoner but was able to escape almost instantly ${ }^{114}$.

Having received the information about the surrender of General Gorgey, the survivors of the Kolozsvar- Székelys units joined forces of the lingering division of Colonel Kazinczy. A Russian parliamentarian brought a letter from Gorgei to his brothers in arms suggesting laying down arms. The surrender of the army of Transylvania (24th - 25th of August) elicited outrage of Polish and Hungarian patriots ${ }^{115}$.

Not yielding to persuasion the Polish Legion dispersed only after reaching the areas surrounding Nagybanya. Czechowski broke through to Silesia from where he went to Paris, fearing of the risk of being turned over to tzar and entered the ranks of supporters of the Lambert Hotel ${ }^{116}$. Rucki was hiding in Hungary until the Christmas in 1852 and after having been tried by court martial, he served the sentence of two years in prison in Koszyce. After having been imprisoned for a short period, he was sent to Galicia ${ }^{117}$ once again.

Little is known about the involvement of Wiktor Dobrosielski in the Hungarian war apart from the fact that after his return to the Kingdom of Poland he served a sentence of 4 years of imprisonment in the Zamość fortress ${ }^{118}$. The fates of the veteran of the French Foreign Legion, Aleksander Matuszewicz, a former Austrian officer and second Lieutenant of the Legion, who later became a captain of a honveds unit, Stanisław Szumlański119, a representative of the Prussian officer corps Władysław Miśkiewicz or Leszek Wiśniowski, born in Galicia and conscripted into an Austrian penal company in Komarno, were similar. The participation of Ignacy Mystkowski, who escaped to the Kingdom of Poland in June 1848 , could not be fully confirmed. ${ }^{120}$

Although the casualties suffered during the battle of Temesvar were not major, the demoralised army scattered during the retreat and only approx. 50\% of the initial forces rallied in Lugos ${ }^{121}$. Walery Kozłowski was captured and became an Austrian prisoner of war in Vilagos where the commander of another army, General Gorgey, surrendered. The Habsburg army deserter was awaiting the sentence of five years of imprisonment in the Munkacz fortress. The Polish Legion acting as the rearguard clashed with the pursuing forces on a daily basis - its last combat action was the defence of a mountain crossing near Teregova during which legionnaires used 2 cannons and were supported by a battalion of honveds ${ }^{122}$. On the 17th of August in Orsza, Kossuth bid farewell to legionnaires and upon

112 E. Kozłowski, Gen. Józef Bem, pp. 475; I. Kovacs, Polscy bohaterowie, pp. 186-187; idem, Polacy w węierskiej Wiośnie Ludów, pp. 304-305; E. Ślaski, Pamiętniki, pp. 347-348.

113 A. Niepokojczycki, Opisanije wojny, pp. 279.

114 I. Kovacs, Polacy w węgierskiej Wiośnie Ludów, p. 305-309; W. Rucki, Ze wspomnień, pp. 210-214.

115 E. Kozłowski, Gen. Józef Bem, pp. 557.

116 M. Budzyński, Wspomnienie mojego życia, Poznań 1880, pp. 263-265.

117 I. Kovacs, Polacy w węgierskiej Wiośnie Ludów, p. 309; W. Rucki, Ze wspomnień, p. 243.

118 J. Giergielewicz, Wiktor Dobrosielski (1827-1898), PSB, vol. 5, Kraków 1939-1946, pp. 248-249.

119 Stanisław Szumlański (1818-1866), PSB, vol. 49, Kraków 2013-2014, p. 356 J. Wysocki, Pamiętnik, p. 147.

${ }^{120}$ M. Bartniczak, Ignacy Mystkowski (1826-1863), PSB, vol. 22, Kraków 1977, pp. 275-276.

121 E. Kozłowski, Legion Polski, p. 285; Z. Miłkowski, Od kolebki, vol. 1, p. 356.

122 E. Kozłowski, Legion Polski, p. 288. 
the request of Wysocki he awarded 26 of legionnaires with the Order of Merit, third class. The justification for his actions near Temesvar, prepared for Major Horodyński, was as follows: as the commander of a battalion [...] he faced the most fierce artillery fire: the casualties reached nearly the half of his forces, including material losses, which speaks volumes of their steadfastness; keeping his soldiers in high spirits he retained order among his forces till the very end and later covered the retreat ${ }^{123}$.

The legionnaires left Hungary between the 18th and the 20th of August. The commander of the Polish Legion gave a farewell speech to the Hungarian people: We have fought arm in arm and, as you know it well, not as mercenaries, not for personal gain, but in hope that your victory and our participation in it will become the foundation of future efforts which are the continual goal of our lives; the fight for the liberty of Poland without which Hungary cannot win nor keep its own liberty ${ }^{124}$.

The fights for your freedom and ours concluded with the stay of 1030 former legionnaires in the territory of Turkey where they were interned and detained in Widin, Szumia and Kutahya. Józef Wysocki was among four detained generals but the requirement of converting to a different creed deterred him from entering into Ottoman service ${ }^{125}$. Second Lieutenant of honveds, Edward Dunajewski, was verified in Szumia (30th of December 1849). Karol Kalita was detained in Szumia and sentenced to 8 months of arrest in Temesvar after his return to the Habsburg Empire, while the punishment of 60 lashes was changed to the renewed conscription into the Austrian army. Edmund Ślaski, captured during the war, was conscripted into imperial armed forces, where he gained the rank of Oberlieutenant of General Staff through service.

The attempt at the assessment of the combat experience gained by the future Polish insurrectionist commanders and its application in fights on own territory will be made in the second part of the article.

\section{"The Hungarian track". From the Spring of Nations (1848-1849) in the territory of the Crown of Saint Stephen to the Polish Uprisings (1863-1864), Vol. I Summary}

During the Spring of Nations in the lands of the Crown of St. Stephen (1848-1849), traditional ties of friendship, with the possibility of a military confrontation occurring with one, two invaders attracted a large crowd of Polish volunteers for the formation of the Hungarian honveds. About 4,000 Poles were fighting directly in the ranks of the revolutionary army, and enrolled to the national legions under the command of Generals Joseph Wysocki alongside the Transylvanian Army Fieldmarshal Joseph Bem. Among them, about 20 individuals who will be later on commanders of the guerrilla armed troops of the January Uprising (1863-1864). For this reason, it is worth recalling the experience that the military group acquired

\footnotetext{
${ }^{123}$ I. Kovacs, Nieznani polscy bohaterowie, pp. 208-209, p. 214.

124 W. Zamoyski, Jenerał Zamoyski, vol. 5, pp. 266; J. Wysocki, Pamiętnik, pp. 132-133; I .Kovacs, Nieznani polscy bohaterowie, p. 68; M. Wieliczko, Polacy na Wegrzech, Lublin 1977, p. 55.

125 As described by, for instance: K. Dopierała, Emigracja polska w Turcji w XIX i XX w., Lublin 1988, pp. 117-123; A. Lewak, Dzieje emigracji polskiej w Turcji 1831-1878, Warszawa 1935, pp. 62-86.
} 
during the battles for the Hungarian Plain, Slovakia, Bukovina, Moldavia, Banat, Backa and Transylvania.

Keywords: Spring of Nations 1848-1849 in Europa; Hungarian Revolution/Uprising against the Habsburg dynasty; Polish Legion in the lands of the Crown of St. Stephen; insurgent leadership cadre

About the Author: Adam Buława, Ph. D., adjunct at the Institute of Historical Sciences of the Cardinal Stefan Wyszyński University in Warsaw, scientific interests: military history, Polish and general history of the nineteenth century, fate of the Poles in exile. 